\title{
Klasyczny reportaż podróżniczy jako forma propagandy politycznej oraz przekazu wiedzy o świecie i kulturze. Ksiq̨iki Arkadego Fiedlera o Madagaskarze
}

STRESZCZEnIE: Tematem artykułu są książki Arkadego Fiedlera (1894-1985) o Madagaskarze, stanowiące efekt dwóch podróży pisarza do tego afrykańskiego kraju, z lat 1937-1938 i 1965-1966: Jutro na Madagaskar! (1939), Źarliwa wyspa Beniowskiego (1944), Radosny ptak Drongo (1946), Goraca wieś Ambinanitelo (1953 i nowa redakcja z 2006), Wyspa kochających lemurów (1957), Madagaskar okrutny czarodziej (1969). Autor opracowania omawia przekaz edukacyjny i propagandowy, konstruowany przez podróżnika w tych publikacjach w różnej rzeczywistości historyczno-politycznej, a także kwestię recepcji książek A. Fiedlera o Madagaskarze. Opiera się głównie na reportażach pisarza i ich recenzjach. Uwzględnia też m.in. wspomnienia A. Fiedlera, jak również głosy osób, wypowiadających się na internetowych portalach czytelniczych. Wykazuje, że książki A. Fiedlera dotąd wzbudzają zainteresowanie i emocje.

SŁoWA KLUCzowE: Fiedler Arkady (1894-1985), reportaż podróżniczy, Madagaskar. 


\section{Wprowadzenie}

orobek reporterski Arkadego Fiedlera $(1894-1985)^{1}$ należy do kla-
syki polskiego reportażu podróżniczego. Autor wydał dużo książek poświęconych podróżom, jakie odbywał od lat dwudziestych XX w. ${ }^{2}$. Dotąd wywiera duży wpływ na odbiorców, przekazując wiedzę o świecie i kulturze oraz kształtując poglądy. Uprawiał propagandę polityczną. Umiejętnie łączył przekazywanie treści edukacyjnych z dawaniem rozrywki. Zasięg społeczny publikacji A. Fiedlera jest duży ze względu na rozległy zakres wiekowy kręgu czytelników, od starszych dzieci po osoby dorosłe.

Większość książek podróżniczych autora dotyczyła Ameryki Południowej. Wśród dzieł A. Fiedlera, stanowiących zapis wrażeń z podróży na inne kontynenty, zwracają uwagę reportaże z kraju afrykańskiego: Madagaskaru. Celem artykułu jest omówienie przekazu edukacyjnego i propagandowego, skonstruowanego przez podróżnika w tych publikacjach, kierowanego do odbiorców w różnej rzeczywistości historyczno-politycznej, a także kwestii recepcji książek A. Fiedlera o Madagaskarze. Autor opracowania oparł się głównie na reportażach pisarza i ich recenzjach. Uwzględnił też m.in. wspomnienia A. Fiedlera, a także głosy osób, wypowiadających się na internetowych portalach czytelniczych.

1 Zob. m.in. E.G. [E. Głębicka], Fiedler Arkady (1894-1985), [w:] Współcześni polscy pisarze i badacze literatury. Słownik biobibliograficzny, pod. red. J. Czachowskiej, A. Szałagan, t. drugi $C-F$, Warszawa 1994, s. 297-300; BT [B. Tylicka], Fiedler Arkady, ur. 1894 w Poznaniu, zm. 1985 tamże, [w:] Słownik literatury dziecięcej i młodzieżowej, pod red. B. Tylickiej, G. Leszczyńskiego, Wrocław, Warszawa, Kraków 2002, s. 116-117; O. Jernas, Arkady Fiedler. Człowiek bez paszportu, Poznań 2013 (wywiad z synami A. Fiedlera: Radosławem Arkadym Fiedlerem i Markiem Fiedlerem). Zob. też książki popularnonaukowe o Arkadym Fiedlerze: A. R. Fiedler, Barwny świat Arkadego Fiedlera, Poznań 1977; B. Tylicka, Arkady Fiedler, Warszawa 1989; K. Fiołka, Fiedler, Warszawa 2011; J. Kuffel, Arkady Fiedler. Podróżnik i literat, Bydgoszcz, Puszczykowo 2012 (album); W. Walkowska, Podróże z Arkadym Fiedlerem, Warszawa 2014. Zob. też strona internetowa Muzeum Arkadego Fiedlera w Puszczykowie [online] [dostęp 13 kwietnia 2018]. Dostępny w World Wide Web: http://fiedler.pl/.

${ }^{2}$ Arkady Fiedler. Poradnik bibliograficzny, oprac. U. Bzdawka, Poznań 1984, s. 5-6, 35-36. 


\section{Jutro na Madagaskar! (1939) i Wyspa, która wabi (1944)}

A. Fiedler odbył pierwszą podróż na Madagaskar w l. 1937-1938³. Kraj ten stanowił wówczas francuską kolonię. Reporter udał się tam w związku z badaniami nad możliwościami kolonizacji ludności, emigrującej z Polski, prowadzonymi na afrykańskiej wyspie przez polską komisję studiów osiedleńczych. Komisję tworzyli: dawny adiutant Józefa Piłsudskiego major Mieczysław Lepecki, reprezentant żydowskiego towarzystwa emigracyjnego Jeas z Paryża Leon Alter i agronom z Tel Awiwu Salomon Dyk. A. Fiedlera namówił do wyjazdu Bogusław Miedziński, pełniący funkcję redaktora sanacyjnej „Gazety Polskiej”. Pisarz miał badać i popularyzować perspektywy kolonizacji. Część kosztów podróży została sfinansowana przez polskie Ministerstwo Spraw Zagranicznych (MSZ) ${ }^{4}$. A. Fiedler powrócił do ojczyzny z gotowym tekstem reportażu Jutro na Madagaskar! ${ }^{5}$. Pierwsze wydanie ogłoszono w 1939 r. w Warszawie 6 . Nieco wcześniej, bo w 1938 r., ukazał się książkowy raport majora M. Lepeckiego z prac komisji, stanowiący wyraz wiary autora w dobre perspektywy współdziałania Polski i Francji ${ }^{7}$.

Autor Jutro na Madagaskar! odniósł się do planów kolonizacji m.in. w rozdziale 27 - Ankezina, kraina błogich chmur ${ }^{8}$, bo to ta część Madagaskaru była proponowana przez stronę polską jako główny obszar polskiego i żydowskiego osadnictwa. Otwarcie zaznaczył, że pomimo pewnych walorów dla potencjalnej działalności rolniczej i hodowlanej, dolina rzeki Ankeziny nie nadaje się do prac rolnych z uwagi na ogromne trudności, jakie przyniosłaby walka z potężnym wodnym żywiołem? 9 W zakończeniu książki dał wyraz nadziei w „polskie jutro na Madagaska-

3 Tamże, s. 6.

${ }^{4}$ A. Fiedler, Madagaskar okrutny czarodziej, Wyd. 3, Warszawa 1982, s. 67-68; Tenże, Wiek męski - zwycięski, Poznań 1983, s. 132-140 (wspomnienia A. Fiedlera).

${ }^{5}$ A. Fiedler, Wiek męski - zwycięski..., s. 140.

${ }^{6}$ Arkady Fiedler. Poradnik bibliograficzny..., s. 17; EG [E. Głębicka], dz. cyt., s. 298.

7 Zob. M. B. Lepecki, Madagaskar. Kraj. Ludzie. Kolonizacja, Warszawa 1938, m.in. s. 297-298.

${ }^{8}$ A. Fiedler, Jutro na Madagaskar!, Wyd. 3, Warszawa 1940, s. 216-224. Zob. też wydanie pierwsze: Tenże, Jutro na Madagaskar!, Warszawa 1939.

9 Tenże, Jutro na Madagaskar..., Warszawa 1940, s. 222-223. 
rze" z zastrzeżeniem, iż aby realizować podobne zamierzenia, konieczna będzie umiejętna współpraca RP z Francją ${ }^{10}$. Były to jednak propagandowe słowa, pisane bez większego przekonania, zważywszy na przedstawioną wcześniej analizę warunków naturalnych.

W znacznie późniejszych wspomnieniach autor w pełni ujawnił swój stosunek do pomysłów kolonizacyjnych, nazywając komisję M. Lepeckiego „nieszczęsną” oraz podkreślając nieprzydatność malgaskich terenów do takich celów. Informował o ujemnym stosunku francuskich władz do propozycji ze strony RP, jaskrawo widocznym w prasie, wydawanej na Madagaskarze pod koniec lat trzydziestych ${ }^{11}$.

Pomysły niektórych polityków i publicystów, aby zmniejszyć liczbę ludności żydowskiej w Polsce poprzez zorganizowanie jej emigracji na Madagaskar, traktował sceptycznie, o czym świadczy fragment Jutro na Madagaskar!, będący zapisem rozmowy z francuskim urzędnikiem kolonialnym, kończący rozdział poprzedzający propagandowe podsumowanie książki. Urzędnik powiedział, że „fantaści” „niebezpieczni dla ogółu”, pragnący „nasłać” Francuzom „trzydzieści tysięcy Żydów”, powinni zostać zamknięci w obozach koncentracyjnych. A. Fiedler nie popierał takich metod, ale przytoczenie słów urzędnika bezpośrednio przed zakończeniem, jest dowodem na jego krytycyzm wobec hasła „Żydzi na Madagaskar”. W innych częściach reportażu dał wyraz swemu zrozumieniu dla Żydów, pisząc np. o trudnym charakterze jednego z towarzyszy podróży: czternastoletniego Jeana, będącego pół Żydem po matce, pochodzącej z Odessy oraz ćwierć Hindusem i ćwierć Malgaszem po ojcu. Dopatrywał się przyczyn w „nieszczęsnych odpryskach odeskiego getta”"12.

Jutro na Madagaskar! zawiera treści poznawcze i wychowawcze. Autor przekazał liczne wiadomości o historii Madagaskaru, w tym odnoszące się do początków kolonizacji francuskiej, mających miejsce pod koniec XIX w. Odnotował fakt eksploatacji gospodarczej wyspy przez Europejczyków, przez co dał do zrozumienia, iż ma krytyczny stosunek wobec takiej polityki. Wprowadził nieśmiałe akcenty antykolonialne, krytykując handel niewolnikami oraz przedmiotowy erotyczny stosunek

10 Tamże, s. 273-276.

11 Tenże, Wiek męski - zwycięski..., s. 140.

12 Tenże, Jutro na Madagaskar..., Warszawa 1940, s. 245-254 (przywołany cytat na s. 253). 
kolonizatorów do tubylczych kobiet ${ }^{13}$. Nadał książce wymowę antyrasistowską, pisząc w ostatnich zdaniach reportażu: „Obecność krwi białej rasy nie tłumi tu wesołości. Na Madagaskarze krew białej rasy podlega tym samym prawom natury, co krew innych ras. Na Madagaskarze u ludzi rasy białej nie zanikł zdrowy śmiech"14. Powyższymi słowami wykazał, iż traktuje różne ludzkie rasy jako równorzędne w stosunku do siebie nawzajem.

Zainteresowanie odbiorców Jutro na Madagaskar! wzbudzały informacje o polskich akcentach w dziejach wyspy: na temat Maurycego Beniowskiego (1746-1786), jak również innego naszego rodaka - opiekuna trędowatych, misjonarza jezuity ks. Jana Beyzyma (1850-1912) ${ }^{15}$. Pisarz, uwydatniając wątki polskie, czynił egzotyczną ziemię bardziej bliską emocjonalnie rodakom, czytającym książkę.

Tolerancja A. Fiedlera wobec obcych kultur nie kłóciła się z negatywnym stosunkiem do wierzeń i zabobonów, bliskich malgaskiej ludności, nazwanych przez niego „Ponurą jaskinią o zatęchłych norach" ${ }^{16}$. Miejscowe przesądy nie fascynowały reportera, ale nasuwały refleksję o konieczności popularyzacji oświaty wśród tubylców.

Reportażowi nadają zalety poznawcze i powiększają jego wartość estetyczną sugestywne opisy przyrody: krajobrazu, np. górskiego i oceanicznego oraz roślin ${ }^{17}$. Reporter przeznaczył bardzo dużo miejsca na opisy fauny i jej zachowań. Na przykładzie przyjaznego nastawienia do małych, dających się oswoić ssaków - lemurów, uczył czytelników humanitarnego stosunku do zwierzą ${ }^{18}$.

W 1944 r., gdy A. Fiedler przebywał na emigracji, w Wielkiej Brytanii ukazała się jego druga książka o Madagaskarze - Żarliwa wyspa Beniowskiego ${ }^{19}$. Pierwsza część dzieła - Wyspa, która wabi, była ponowną publikacją i zarazem przeróbką tekstu Jutro na Madagaskar! ${ }^{20}$. Twórca

13 Tamże, s. 7-8, 12-18, 27-29, 51-71, 81-89, 100-103, 127-135, 139-140, 172$-177,189-197$.

14 Tamże, s. 277.

15 Tamże, s. 71-80, 198-199.

16 Tamże, m.in. s. 31-32, 35-42, 46-49 (przywołany cytat - na s. 35).

17 Tamże, s. 5, 12, 19, 27, 29, 97-98, 149-150.

18 Tamże, s. 120-126, 225-261.

19 Arkady Fiedler. Poradnik bibliograficzny..., s. 35; EG [E. Głębicka], dz. cyt., s. 299.

20 Zob. A. Fiedler, Żarliwa wyspa Beniowskiego, Lechtworth Printers Ltd, Lechtwoth Herts 1944, s. [9]-111 (część pierwsza Wyspa, która wabi). 
odebrał reportażowi wymowę i pointę polityczną, usuwając fragmenty o planach kolonizacji z terenu Polski na Madagaskar, w tym odnoszące się do kwestii żydowskiej ${ }^{21}$, nieaktualne w wojennych realiach. Zmienił wydźwięk książki z politycznego na ekologiczny, poprzez zamknięcie narracji rozdziałem Bokombolo jest szary, nie będącym zakończeniem Jutro na Madagaskar!22. Wzmocnił efekt, dopisując ostatnie zdanie do tego rozdziału i zarazem całego reportażu: „Zwierzęta są często jak ludzie: potrzeba im tylko trochę ciepła ludzkiej życzliwości, by nagle z ukrytych głębi buchnęły źródła nowych uczuć i trysnęły niespodziane wartości

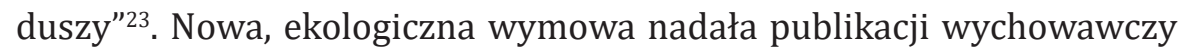
i zarazem uniwersalny charakter.

\section{Radosny ptak Drongo (1940-1941, 1944, 1946)}

Inny reportaż A. Fiedlera z podróży na Madagaskar z okresu 1937-1938 to Radosny ptak Drongo, stanowiący opis pobytu w malgaskiej wsi Ambinanitelo. Pisarz pracował nad tekstem, przebywając w 1939 r. na Tahiti ${ }^{24}$. Niewielka część Radosnego ptaka Drongo została wydrukowana w latach 1940-1941 w odcinkach pod tytułem Goraca wieś Ambinanitelo, w emigracyjnym tygodniku „Wiadomości Polskie”, wydawanym w Londynie ${ }^{25}$.

${ }^{21}$ Zob. tamże, s. [9]-111; Tenże, Jutro na Madagaskar..., Warszawa 1940.

22 Tenże, Żarliwa wyspa Beniowskiego..., s. 107-111; Tenże, Jutro na Madagaskar..., Warszawa 1940, s. 255-261.

${ }^{23}$ Tenże, Żarliwa wyspa Beniowskiego..., s. 111.

${ }^{24}$ J. Ratajczak, Gdy Warta wpadała do Ukajali (szkice o Arkadym Fiedlerze), Poznań 1994, s. 81-82.

${ }_{25}$ Zob. A. Fiedler, Biada zwycięzcy! Z cyklu Gorqca wieś Ambinanitelo, „Wiadomości Polskie Polityczne i Literackie” 1940, nr 10, s. 3 [cz. 1]; Tenże, Gorq̨ca wieś Ambinanitelo. Mimozy. Malgaski kogut, „Wiadomości Polskie Polityczne i Literackie” 1940, nr 28/29, s. 1 [cz. 2]; Tenże, Gorqca wieś Ambinanitelo. Owady się modlą. Kameleon, „Wiadomości Polskie Polityczne i Literackie” 1940, nr 31, s. 3 [cz. 3]; Tenże, Gorąca wieś Ambinanitelo. Wzgórze Beniowskiego. Barwna śmierć, „Wiadomości Polskie Polityczne i Literackie” 1940, nr 34, s. 2 [cz. 4]; Tenże, Gorąca wieś Ambinanitelo. Las jest moim przyjacielem. Pająki i modliszki, „Wiadomości Polskie Polityczne i Literackie” 1940, nr 38, s. 3 [cz. 5]; Tenże, Goraca wieś Ambinanitelo. Duch Beniowskiego. Magia przyrody, „Wiadomości Polskie Polityczne i Literackie" 1941, nr 3, s. 2 [cz. 6]; Tenże, Gorąca wieś Ambinanitelo. Głodna krew, „Wiadomości Polskie Polityczne i Literackie” 1941, nr 5, s. 2 [cz. 5]; Tenże, Gorąca wieś Ambinanitelo. Wąż Ankoma, „Wiadomości Polskie Polityczne i Literackie” 1941, nr 8, s. 3 [cz. 8]. Zob. też EG [E. Głębicka], dz. cyt., s. 298. 
Pierwszą pełną publikacją stała się cześć druga książki Żarliwa wyspa Beniowskiego z 1944 r., mająca tytuł Radosny ptak Drongo ${ }^{26}$. Autor jeszcze mocniej, niż w Jutro na Madagaskar!, dał wyraz światopoglądowi antyrasistowskiemu. Zdecydowanie potępił niewolnictwo, bowiem tytułowy ptak Drongo to główny bohater malgaskiej opowieści, w której handel niewolnikami ukazano jako zjawisko negatywne ${ }^{27}$. A. Fiedler zakończył reportaż, pisząc o „swych brązowych przyjaciołach”, „brązowym człowieku”, mającym się cechować „pogodnym i uczciwym umysłem”, a także używając sformułowania „śmiercionośne odmęty białej rasy”"28. W toku reportażowej fabuły ostro skrytykował postępowanie kolonialistów, gnębiących Madagaskar ekonomicznie. Odważnie wprowadził wątek obyczajowy i erotyczny, wspominając tubylcze zwyczaje miłosne, jak również swą malgaską towarzyszkę - dziewczynę o imieniu Velomody i jej siostrę Benaczehinę ${ }^{29}$. Wspomnienia A. Fiedlera, związane z malgaskimi kobietami, przypomniano później w książce Kobiety mej młodości, wydanej po śmierci autora ${ }^{30}$.

W Radosnym ptaku Drongo pisarz przeznaczył o wiele więcej miejsca, aniżeli w przypadku Jutro na Madagaskar!, na popularyzację postaci M. Beniowskiego ${ }^{31}$.

Opisał z pasją przyrodę Madagaskaru, przede wszystkim zwierzęta, między nimi motyle ${ }^{32}$. Pisał z miłością o malgaskiej puszczy ${ }^{33}$. Opisami przyrody, w tym zwierząt, przekazywał czytelnikom wiadomości przyrodnicze oraz rozbudzał i rozwijał zamiłowanie do natury. Wiedzę o mal-

${ }^{26}$ Zob. A. Fiedler, Żarliwa wyspa Beniowskiego..., s. [113]-230 (część druga Radosny ptak Drongo). Zob. też Arkady Fiedler. Poradnik bibliograficzny..., s. 29-30; EG [E. Głębicka], dz. cyt., s. 299.

27 A. Fiedler, Żarliwa wyspa Beniowskiego..., m.in. s. 116, 141-143, 154, 194.

28 Tamże, s. 230.

29 Tamże, s. 157-161, 171, 176-181, 195-207, 223.

30 Tenże, Kobiety mej młodości. Rzeczy wybrane, Poznań 1989, s. 56-82, 84-86. Cytowana książka zawiera po części przedruki z wcześniej wydanych reportaży Fiedlera.

31 Tenże, Żarliwa wyspa Beniowskiego..., s. 115-117, 136-139, 167-170, 227-229. Wiadomości o działalności Beniowskiego na Madagaskarze - zob. m.in. M. Beniowski, Pamiętniki, tł. E. Kajdański, Warszawa 1995, s. 427-596; E. Kajdański, Przedmowa tłumacza, [w:] M. Beniowski, dz. cyt. s. 9-10.

32 A. Fiedler, Żarliwa wyspa Beniowskiego..., s. 115, 123-131, 145-148, 153-156, 162-165, 187-191, 213-214, 224-226.

33 Tamże, s. 140-141. 
gaskiej faunie popularyzowano także w dwóch pośmiertnych książkach A. Fiedlera: Motylach mego życia ${ }^{34}$ i Zwierzętach mego życia ${ }^{35}$.

Autor, pisząc o kulturze ludowej, udokumentował przesądy związane z naturą i zanotował teksty niektórych pieśni, jakie słyszał w Ambinanitelo ${ }^{36}$.

Osobne wydanie książkowe Radosnego ptaka Drongo wyszło drukiem w 1946 r. na terenie Wielkiej Brytanii ${ }^{37}$. Reportaż był też drukowany w odcinkach na łamach krakowskiego tygodnika „Przekrój”38.

\section{Gorąca wieśs Ambinanitelo (1953, 2006)}

Książka A. Fiedlera Gorąca wieś Ambinanitelo, wydana po raz pierwszy w 1953 r. $^{39}$, to przerobiona i znacznie rozwinięta wersja Radosnego ptaka Drongo.

Reporter wykorzystał dużą część tamtego tekstu, wprowadzając czasem przeróbki. Uzupełnił Gorącq wieś Ambinanitelo o nowe rozdziały, napisane w duchu ideologii, obowiązującej w Polsce Ludowej. Wprowadził też inne aktualizacje historyczno-polityczne ${ }^{40}$.

Dodał tendencyjnie zarysowaną postać: nauczyciela Ramaso z Ambinanitelo, symbolizującego ideologię komunistyczną i postępowość ${ }^{41}$. Nauczyciel miał czytać książki Karola Marksa, Fryderyka Engelsa, Włodzimierza Lenina i Józefa Stalina ${ }^{42}$. A. Fiedler dopisał dwa stronnicze

34 Tenże, Motyle mego życia. O wielkiej miłości i wielu miłostkach, Poznań 1983, s. 110-145. Przywołana publikacja zwarta jest w dużej mierze zbiorem przedruków z wcześniejszych książek autora.

35 Tenże, Zwierzęta mego życia. Rzeczy wybrane, Poznań 1985, m.in. s. 111-141 (po części - przedruki z Radosnego ptaka Drongo).

36 Tenże, Żarliwa wyspa Beniowskiego..., s. 176-186, 208-212.

${ }^{37}$ Arkady Fiedler. Poradnik bibliograficzny..., s. 25; EG [E. Głębicka], dz. cyt. s. 299. Zob. też A. Fiedler, Radosny ptak Drongo, Lechtworth Herts, Lechtworth Print 1946.

38 Zob. Tenże, Radosny ptak Drongo, „Przekrój” 1946, nr 78, s. 19-20 (jeden z odcinków) (odcinki - nie numerowane).

39 Arkady Fiedler. Poradnik bibliograficzny..., s. 14; EG [E. Głębicka], dz. cyt., s. 298.

${ }^{40}$ Zob. A. Fiedler, Goraca wieś Ambinanitelo, Warszawa 1953; Tenże, Żarliwa wyspa Beniowskiego..., s. [113]-230; Tenże, Radosny ptak Drongo... .

41 Tenże, Gorq̨ca wieś Ambinanitelo..., m.in. s. [30], 57, 60-69, 86-93, 108-120, $165,221$.

42 Tamże, s. 65-69. 
przypisy. W jednym użył terminu klasy rządzące ${ }^{43}$, zaś w drugim, bardzo rozbudowanym, omówił działalność partii o nazwie Ruch Demokratycznego Odrodzenia Malgaskiego (MDRM) ${ }^{44}$ (franc. Mouvement Démocratique de la Rénovation Malgasche).

Rozwinął wątek antykolonialny, omawiając bunt grupy Malgaszów organizatorów strajku na francuskich plantacjach, antykolonialne zamieszki i wojskowo-policyjne represje ${ }^{45}$. Dodał do dawnego tekstu także m.in. rozdział Pola ryżowe, omawiający sprawy społeczno-gospodarcze wsi Ambinanitelo ${ }^{46}$.

Historię Madagaskaru przedstawił po części w ujęciu propagandowo-antyrasistowskim, antykolonialnym i antykapitalistycznym ${ }^{47}$. Podkreślił, iż „Madagaskar stał się natychmiast po zdobyciu przez Francję folwarkiem wyzysku kapitalistycznego"48. Nawiązując do dawniejszych czasów, przypomniał M. Beniowskiego ${ }^{49}$.

W zakończeniu książki, będącym przeróbką końcowego fragmentu Radosnego ptaka Drongo, A. Fiedler nawiązał do osoby Ramaso, pisząc o wiejskim pedagogu jako o „walecznym bojowniku o lepsze jutro Madagaskaru” i „człowieku nowej epoki”, a także używając sformułowań „nieustający obowiązek walki” i „budowa nowej, prostszej sprawiedliwszej drogi" ${ }^{50}$.

Identycznie, jak w reportażu opublikowanym w latach czterdziestych, skupił się w dużym stopniu na przyrodzie, przekazując czytelnikom wiedzę na temat zwierząt, żyjących na Madagaskarze. Rozwinął wątek, związany z malgaskimi przesądami, odnoszącymi się do natury, dodając nowe fragmenty do niektórych rozdziałów, zawierające krytyczne uwagi jego i Ramaso wobec zabobonów oraz porównanie stosunków w przyrodzie do walki między potęgami imperialnymi ${ }^{51}$.

43 Tamże, s. 110.

44 Tamże, s. 115-117 (przypis zajmuje dolne części trzech kolejnych stron).

45 Tamże, s. 176 i następne.

46 Tamże, s. 50-55.

47 Tamże, s. 74-84, 98-103.

48 Tamże s. 102.

49 Tamże, s. 5, 12, 13, 15, 38-42, 104-108.

50 Tamże, s. 221. Zob. też Tenże, Żarliwa wyspa Beniowskiego..., s. 230 (zakończenie części drugiej Radosny ptak Drongo); Tenże, Radosny ptak Drongo..., s. 142-143.

51 Tenże, Goraca wieś Ambinanitelo..., m.in. s. 29-[30], 58-59; Tenże, Żarliwa wyspa Beniowskiego..., m.in. s. 126, 148-149; Tenże, Radosny ptak Drongo... 
Ograniczył wątek erotyczny, pozostawiając wspomnienia o Velomody, ale minimalizując uwagi o Benaczehinie, zanotowane w Radosnym ptaku Drongo w rozdziale $A$ to co, do licha!?, nie wykorzystanym przy rozwijaniu tekstu w książkę Goraca wieś Ambinanitelo ${ }^{52}$.

Nowego opracowania tekstu Gorącej wsi Ambinanitelo dokonał Wojciech Cejrowski, przygotowując wydanie w ramach serii Biblioteka Poznaj Świat. Redaktor usunął stronnicze wstawki z 1953 r., przenosząc najważniejsze do aneksu ${ }^{53}$. Przywrócił całość wątku, związanego z malgaskimi towarzyszkami pisarza ${ }^{54}$.

Najważniejszą zmianą było nadanie publikacji z 2006 r. nowoczesnej szaty graficznej. Udoskonalono cyfrowo czarno-białe fotografie z wcześniejszych wydań. Redaktor wzbogacił materiał ilustracyjny o liczne, nie publikowane wcześniej zdjęcia autorstwa A. Fiedlera, wykonane w latach trzydziestych na Madagaskarze ${ }^{55}$.

W. Cejrowski, opracowując edycję dostosowaną do wrażliwości plastycznej współczesnego odbiorcy i wolną od tendencyjności politycznej, dobrze się przysłużył popularyzacji książki A. Fiedlera, umożliwiając jej nową recepcję.

\section{Wyspa kochających lemurów (1957)}

Wyspa kochających lemurów A. Fiedlera z 1957 r. stanowi zaktualizowane autorskie opracowanie reportażu Jutro na Madagaskar! z 1939 r. ${ }^{56}$, wydrukowane na krótko przed uzyskaniem przez Madagaskar autonomii

52 Tenże, Gorq̨a wieś Ambinanitelo...; Tenże, Żarliwa wyspa Beniowskiego..., s. [113]-230 (m.in. s. 197-202 - rozdział 19 A to co, do licha!?) (część druga Radosny ptak Drongo); Tenże, Radosny ptak Drongo..., m.in. s. 104-109 (rozdział 19 A to co, do licha!?).

53 Tenże, Madagaskar - gorąca wieś Ambinanitelo, opracowanie plastyczne W. Cejrowski, Pelplin 2006, m.in. s. 355-365 (aneks).

54 Tamże, m.in. s. 229-235 (rozdział Tajemnica miłości, czyli dawny rozdział A to co, do licha!?, przywrócony przez W. Cejrowskiego w wydaniu z 2006 r., usunięty wcześniej z pierwszego wydania Goracej wsi Ambinanitelo z 1953 r.); Tenże, Żarliwa wyspa Beniowskiego..., s. 197-202 - rozdział 19 A to co, do licha!?) (część druga Radosny ptak Drongo); Tenże, Radosny ptak Drongo..., s. 104-109 (rozdział 19 A to co, do licha!?); Tenże, Gorąca wieś ..., Warszawa 1953.

55 Tenże, Madagaskar - gorąca wieś Ambinanitelo... . Zob. też [W. Cejrowski], Kilka słów o zdjęciach, [w:] A. Fiedler, Madagaskar - gorq̨ca wieś Ambinanitelo..., s. 349-350.

${ }^{56}$ Arkady Fiedler. Poradnik bibliograficzny..., s. 30-31. 
w 1958 i niepodległości w 1960 r. Pisarz oparł nową wersję opisu podróży z lat trzydziestych na przeróbce z $1944 \mathrm{r}^{57}$.

Zasadniczy zabieg aktualizacyjny, logiczny i prosty, to zmiana czasu w głównym wątku narracji autorskiej z teraźniejszego na przeszły ${ }^{58}$.

W wersji z 1957 r. nie pojawiły się fragmenty o pomysłach polskiej kolonizacji na Madagaskarze, nieobecne już w Wyspie, która wabi ${ }^{59}$. Dodatkowa, powojenna aktualizacja polegała na wprowadzeniu elementów propagandy politycznej, zgodnej z poglądami, głoszonymi przez władze PRL. Chodzi o krytycyzm w stosunku do kolonializmu i zabobonów, cechujący A. Fiedlera niezależnie od zmian politycznych na świecie i w Polsce, ale celowo wyeksponowany w Wyspie kochających lemurów ${ }^{60}$. Pod koniec lat trzydziestych napisał np.

Malgasze, wiadomo, nie cierpią pracy, jak diabeł wody święconej; gdy mają się ruszyć, jęczą; gdy mają coś zrobić, wolą prawie umrzeć ${ }^{61}$.

Przywołane zdanie ma ten sam sens w książce z $1944 \mathrm{r}^{62}$. W drugiej połowie lat pięćdziesiątych autor napisał:

Malgasze, wiadomo, nie cierpieli pracy dla białych ludzi jak diabeł wody święconej; gdy mieli się ruszyć, jęczeli; gdy mieli coś zrobić, woleli prawie skonaćc ${ }^{6}$.

Rozdział 6 Fadi, stanowiący opis przykładu malgaskich zabobonów, zakończył dopisując w Polsce Ludowej zdanie:

57 A. Fiedler, Wyspa kochających lemurów, Wyd. 3, Warszawa 1986; Tenże, Jutro na Madagaskar..., Warszawa 1940...; Tenże, Żarliwa wyspa Beniowskiego..., s. [9]-111.

58 Tenże, Wyspa kochających lemurów...; Tenże, Jutro na Madagaskar..., Warszawa 1940 ...; Tenże, Żarliwa wyspa Beniowskiego..., s. [9]-111.

59 Tenże, Wyspa kochających lemurów...; Tenże, Jutro na Madagaskar..., Warszawa $1940 \ldots$...; Tenże, Żarliwa wyspa Beniowskiego..., s. [9]-111.

60 Tenże, Wyspa kochających lemurów..., m.in. s. 8-9, 11-12, 20, 24, [31], 74-78, 84-86. Zob. analogiczne fragmenty: Tenże, Jutro na Madagaskar..., Warszawa 1940...; Tenże, Żarliwa wyspa Beniowskiego..., s. [9]-111.

61 Tenże, Jutro na Madagaskar..., Warszawa 1940, s. 147.

62 Tenże Żarliwa wyspa Beniowskiego..., s. 82.

63 Tenże, Wyspa kochających lemurów..., s. 85-86. 
Od tego czasu tym głębsze żywiłem uczucie przyjaźni i podziwu dla wszystkich bojowników malgaskich, toczących walkę o wydobycie się z resztek ciemnoty ${ }^{64}$.

Uzupełnił rozdział o ks. J. Beyzymie uwagą o małym zainteresowaniu kolonizatorów postacią Polaka oraz końcowym zdaniem, brzmiącym

A jednak wydaje mi się, że niezwykłe bohaterstwo i ogromne poświęcenie Jana Beyzyma, apostoła malgaskich trędowatych, nie powinno pójść w niepamięć nas, Polaków ${ }^{65}$.

Rezygnując, analogicznie jak w czasie II wojny światowej, z pointy politycznej reportażu, pozostawił wymowę ekologiczną. Wzmocnił efekt, zmieniając tytuł ostatniego rozdziału (Bokombolo jest szary $w$ Wyspie, która wabi) na Lemur Bokombolo spragniony ciepła ${ }^{66}$ i tytułując nową wersję całej książki: Wyspa kochających lemurów. Ostatnie zdanie publikacji z 1957 r. brzmi tak samo, jak końcowe słowa Wyspy, która wabi ${ }^{67}$. Charakterystyczne jest, że pisarz nie umieścił w zakończeniu wersji tekstu, wydanej po 1956 r., akcentów politycznych, odmiennie niż w wydaniu Gorqcej wsi Ambinanitelo z 1953 r.

\section{Madagaskar okrutny czarodziej (1969)}

Druga podróż A. Fiedlera na Madagaskar odbyła się w innej rzeczywistości historycznej niż pierwsza, bo w latach 1965-1966 pisarz zwiedzał już

64 Tamże, s. [31] (ostatnie zdanie rozdziału 6 Fadi z s. 28-[31]). Zob. też zakończenie tego samego rozdziału w dwóch poprzednich wersjach książki Fiedlera, nie zawierające zacytowanego wyżej zdania: Tenże, Jutro na Madagaskar..., Warszawa 1940, s. 81; Tenże, Żarliwa wyspa Beniowskiego..., s. 55.

65 Tenże, Wyspa kochających lemurów..., s. [47]. Przywołanego fragmentu, zakończonego tym zdaniem, nie ma w tekście tego samego rozdziału w Jutro na Madagaskar! ani w Wyspie, która wabi, zob. Tenże, Jutro na Madagaskar..., Warszawa 1940, s. 80; Tenże, Żarliwa wyspa Beniowskiego..., s. 54-55.

${ }^{66}$ Tenże, Wyspa kochających lemurów..., s. 123-[126] (rozdział 28 Lemur Bokobolo spragniony ciepła, zamykający książkę); Tenże, Żarliwa wyspa Beniowskiego..., s. 107-111 (rozdział 20 Bokombolo jest szary, kończący reportaż Wyspa, która wabi).

${ }_{67}$ Tenże, Wyspa kochających lemurów..., s. [126]; Tenże, Żarliwa wyspa Beniowskiego..., 
niepodległe państwo ${ }^{68}$. Reporterskim owocem wyprawy stała się książka Madagaskar okrutny czarodziej, mająca pierwodruk w $1969 \mathrm{r}^{69}$.

Autor zestawił zastane realia z wrażeniami sprzed prawie trzydziestu lat $^{70}$. Powiększył wartość poznawczą nowej książki o Madagaskarze, nawiązując krytycznie do dawnych publikacji, zawierających wiadomości na temat tego kraju, np. do fragmentu Opisania świata Marco Polo z XIII w. ${ }^{71}$. Popularyzował też książkę Johna Normana Leonarda Bakera Odkrycia i wyprawy geograficzne ${ }^{72}$, a także część opracowania Lecha Ratajskiego Afryka, dotyczącą Madagaskaru ${ }^{73}$.

A. Fiedler przeznaczył dużo miejsca na odniesienia do przeszłości kraju, od dawnej sprzed kolonizacji, przez okres, kiedy Madagaskar był kolonią francuską od połowy lat dziewięćdziesiątych XIX w., po dzieje najnowsze: odzyskanie niepodległości w 1960 r. i początki samodzielnego państwa. Omówienie historii Madagaskaru ma wymowę antykolonialną ${ }^{74}$.

Reporter dał wyraz sprzeciwowi wobec rasizmu, popierając chociażby ideę równości między czarnymi i białymi ludźmi w rozdziale otwierającym książkę, znacząco zatytułowanym Zmieniło się na Oceanie Indyjskim. Tłumaczył wcześniejszą polityką kolonialną niechęć czarnych do białych, którą zauważył podczas podróży statkiem ${ }^{75}$.

s. 111. Zob. też przypis nr 23 do prezentowanego artykułu i zacytowane ostatnie zdanie Wyspy, która wabi, do którego odnosi się ten odsyłacz.

${ }_{68}$ Arkady Fiedler. Poradnik bibliograficzny..., s. 6.

69 Tamże, s. 18-19; EG [E. Głębicka], dz. cyt., s. 300.

70 Arkady Fiedler. Poradnik bibliograficzny..., s. 6.

71 A. Fiedler, Madagaskar okrutny czarodziej..., s. 9-10. Zob. też fragment Opisania świata Marco Polo, przywołany przez Fiedlera, stanowiący opis wyspy Mogdaszo, czyli Madagaskaru, M. Polo, Opisanie świata, tł. A.L. Czerny, wstępem i przypisami opatrzył M. Lewicki, tł. przedmowy U. Eco J. Wajs, Warszawa 2010, s. 379 i następne (rozdział CXCII Tu opowiada się o wyspie Mogdaszo). Marco Polo przedstawił informacje o Madagaskarze jako pierwszy autor. Nie odwiedził afrykańskiej wyspy osobiście, ale oparł się na danych, zebranych przez żeglarzy Arabów, M. Polo, dz. cyt., s. 720 (objaśnienia do rozdziału CXCII).

72 Tamże, s. 9. Zob. też J. N. L. Baker, Odkrycia i wyprawy geograficzne, tł. J. Flis, Warszawa 1959, m.in. s. 46-51 (fragment nt. Marco Polo, przywołany przez Fiedlera).

${ }^{73}$ A. Fiedler, Madagaskar okrutny czarodziej..., s. 96. Zob. też fragment książki Ratajskiego, cytowany krytycznie przez Fiedlera: L. Ratajski, Afryka, Warszawa 1966, s. 376.

74 A. Fiedler, Madagaskar okrutny czarodziej..., s. 12, 38-40, 51-57, 62-66, 76-85, 108-112, 116-118, 128, 138-141, 163-167, 170-171, 199-201.

75 Tamże, s. 7-8. 
Nawiązał do Holokaustu, wspominając spotkanie z mieszkańcem Madagaskaru, Żydem z Wiednia Oskarem Altmannem, któremu udało się wyemigrować z Europy w 1939 r. Pisarz nazwał wojnę, rozpętaną przez Niemców, obłędem, a zagładę Żydów - zmorą ${ }^{76}$.

Starał się wpoić czytelnikom wrażliwość na ubóstwo i choroby, opisując biedę dotykającą Malgaszów i podejmując problem chorych na trąd77. Ocenił źle sytuację gospodarczą kraju, stwierdzając:

Przy [...] szczupłych zasobach naturalnych i przy ogólnym wśród mas ubóstwie czyż dziwić się, że Malgasze od pokoleń przyzwyczaili się wyciągać do obcych łasą rękę? Że dziś, kiedy zaczęli budować własną państwowość, a nie unikali przy tym rozrzutności, że szczególnie dziś musieli wyciągać rękę na wszystkie strony ${ }^{78}$.

Zainteresowanie reportera wzbudziły, tak jak trzy dziesięciolecia wcześniej, przesądy i obrzędy. Najważniejszy opisał w rozdziale Byłem na czumbie, zbiorowej ekstazie ${ }^{79}$. Wśród innych sfer kultury duchowej i artystycznej Madagaskaru, popularyzowanych przez A. Fiedlera, znalazły się sztuka retoryczna i poezja mówiona ${ }^{80}$.

A. Fiedler dzielił się z odbiorcami książki miłością do przyrody wyspy, sugestywnie opisując krajobrazy, szczególnie jezioro Kinkony, a także rośliny i zwierzęta, w tym baobaby i motyle ${ }^{81}$.

Zamieścił w publikacji propagandowy akcent antyamerykański, krytykując działania USA mające miejsce w Wietnamie ${ }^{82}$. Zakończenie książki, powstałej i wydanej w latach sześćdziesiątych, nie było tendencyjne, w przeciwieństwie do ostatnich zdań Goracej wsi Ambinanitelo, ogłoszonej w 1953 r. Reporter, podsumowując wrażenia z powojennej podróży na Madagaskar, podkreślił powierzchowność zmian cywilizacyjnych i obyczajowych ${ }^{83}$.

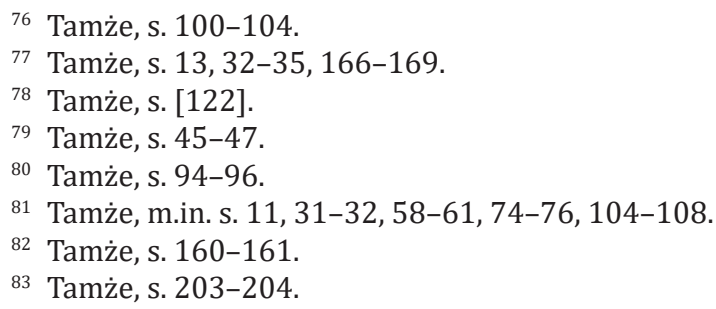




\section{Recepcja książek A. Fiedlera o Madagaskarze}

Książki A. Fiedlera o Madagaskarze spotykały się z żywym odbiorem recenzentów i pozostałych czytelników.

Reportaż Jutro na Madagaskar! został wysoko oceniony przez Ksawerego Pruszyńskiego na łamach „Kuriera Literackiego i Naukowego”. Według recenzenta, pisarz dorównał talentem Rudyardowi Kiplingowi oraz Wacławowi Sieroszewskiemu. K. Pruszyński nazwał A. Fiedlera:

[...] wielkim, może największym z naszych współczesnych pisarzy".

Szydził z planów migracji Żydów na Madagaskar ${ }^{84}$.

Związany z obozem sanacyjnym, pisarz Juliusz Kaden-Bandrowski, wyciągnął z książki wniosek o pomyślnych perspektywach emigracji z Polski do francuskiej kolonii ${ }^{85}$. Publicysta z poznańskiej „Kultury”, Walerian Lachnitt twierdził, że sceptyczny stosunek A. Fiedlera do idei przesiedlenia mniejszości żydowskiej wynika z przekonania reportera, iż Madagaskar winien być „bastionem polskości” jako teren kolonizacyjny ${ }^{86}$. Autor recenzji, zamieszczonej w tygodniku „Pion”, Witold Hulewicz, docenił Jutro na Madagaskar! za syntetyczność wyboru wrażeń, połączoną z wnikliwością opisów, a także za walory edukacyjne i artystyczne. Podkreślił poczytność książek Fiedlera ${ }^{87}$. Podróżnikowi Czesławowi Centkiewiczowi spodobała się antyrasistowska pointa książki ${ }^{88}$.

Z reakcją prasy i czytelników spotkał się też Radosny ptak Drongo. Część odbiorców odniosła się krytycznie do publikacji rozdziału $A$ to, co do licha!? w „Przekroju” z 12 października 1946 r. Autora notatki Zacofane obyczaje Malgaszów, wydrukowanej w „Kuźnicy” z 28 października,

${ }^{84}$ K. Pruszyński, Arkady Fiedler: „Jutro na Madagaskar”, Tow.[arzystwo] Wyd.[awnicze] Rój, Warszawa 1939, str. 280, „Kurier Literacko-Naukowy” 1939, nr 2, s. X-XI (dodatek do nr 9 poczytnego „Ilustrowanego Kuriera Codziennego”).

85 J. Kaden-Bandrowski, „Jutro na Madagaskar”, „Gazeta Polska” 1939, nr 8, s. 12.

${ }^{86}$ W. Lachnitt, Egzotyka, „Kultura” 1939, nr 18, s. 6.

87 W. Hulewicz, Madagaskar Fiedlera, „Pion” 1939, nr 5, s. 5.

${ }^{88}$ Cz. J. Centkiewicz, Lemury i dziewczyny, „Wiadomości Literackie” 1939, nr 4, s. 5. 
podpisanej mn, raziła bezpruderyjność reportera ${ }^{89}$. Na ten sam temat wypowiedział się Paweł Jasienica, gorsząc się w „Tygodniku Powszechnym” z 3 listopada ekshibicjonizmem, mającym być cechą autora Radosnego ptaka Drongo ${ }^{90}$. W „Przekroju” reagowano na zarzuty, żartując iż A. Fiedler nie wyjeżdża obecnie na Madagaskar, obawiając się reakcji rodziny Velomody na odcinkową publikację reportażu ${ }^{91}$. Pisarz odpowiedział na krytykę prasową, podejmując w latach pięćdziesiątych decyzję o nie uwzględnieniu atakowanego rozdziału w książce Goraca wieś Ambinanitelo.

Pierwsze wydanie tego reportażu z 1953 r. zostało dobrze przyjęte przez Ryszarda Wasitę, który wyeksponował elementy propagandowe Goracej wsi Ambinanitelo, pisząc artykuł o A. Fiedlerze dla „Nowej Kultury"92. Wymowę antykolonialną publikacji podkreślił też Henryk Jezierski, recenzując w 1972 r. czwarte wydanie książki ${ }^{93}$.

W maju 1969 r. Wojciech Giełżyński reklamował w „Nowych Książkach” reportaż Madagaskar okrutny czarodziej, stwierdzając: „Fiedler znów z Madagaskaru"94. Wacław Sadkowski dostrzegł w publikacji zalety literackie, uznając ją za przykład „beletrystyki reportażowej”. Położył nacisk na tematykę polityczną i gospodarczą ${ }^{95}$. Trudnościami młodego państwa przejął się również H. Jezierski w recenzji z „Naszego Klubu”"96. Autor artykułu pośmiertnego o A. Fiedlerze, ogłoszonego w kwietniu 1985 r. w „Życiu Literackim”, Janusz Roszko, nawiązał do tytułu nazywając pisarza „egzotycznym czarodziejem”97.

${ }^{99}$ mn, Zacofane obyczaje Malgaszów, „Kuźnica” 1946, nr 42, s. 11. Zob. też A. Fiedler, Radosny ptak Drongo, „Przekrój” 1946..., s. 19-20.

90 Jas [P. Jasienica], Odpowiadam czytelnikom, „Tygodnik Powszechny” 1946, nr 44, s. 12.

91 Wojt., Stołeczne szmery, „Przekrój” 1947, nr 115, s. [16].

92 R. Wasita, Przyjaciel Malgaszów i kanadyjskich sosen, „Nowa Kultura” 1954, nr 44, s. 6.

93 H. Jezierski, Madagaskar Fiedlera, „Książki dla Ciebie” 1972, nr 10 (dodatek do miesięcznika „Nasz Klub”), s. 22.

${ }_{94}$ W. Giełżyński, Fiedler znów z Madagaskaru ,„Nowe Książki” 1969, nr 9, s. 597-598.

95 W. Sadkowski, Nowa powieść Konwickiego - Wybór słuchowisk literackich - Wspomnienia Michała Rusinka - Reportaże publicystyczne i literackie - „Antypowieść” Aragona, „Nowa Szkoła” 1970, nr 1, s. 50-51.

${ }_{96}$ H.J. [H. Jezierski], Madagaskar dzisiaj, „Nasz Klub” 1974, nr 10, s. 24.

97 J. Roszko, Fiedler - egzotyczny czarodziej?, „Życie Literackie” 1985, nr 16, s. 1, 13. 
Malgaskie reportaże A. Fiedlera są przywoływane w publikacjach podróżniczych i opracowaniach o Madagaskarze. Wśród podróżników, relacjonujących wyprawy do tego kraju, przypominających przy okazji pozycje A. Fiedlera, znaleźli się Olgierd Budrewicz ${ }^{98}$, Tomasz Owsiany ${ }^{99}$ i Dorota Kozioł ${ }^{100}$. Przykład książki popularnonaukowej, w której nawiązano do podróży A. Fiedlera na Madagaskar i ich reporterskich owoców, to praca Jana Wiesława Dyskanta Madagaskar 1942, wydana w 2010 r. przez Bellonę ${ }^{101}$. Jezuita ks. Czesław Drążek zacytował Wyspę kochających lemurów w biografii ks. J. Beyzyma ${ }^{102}$.

Karolina Marcinkowska powołuje się na Madagaskar okrutny czarodziej w opracowaniu naukowym z dziedziny antropologii z 2016 r., będącym efektem badań terenowych nad kultem czumba, praktykowanym w tym kraju. Przyjęła na potrzeby pracy polską pisownię terminu „czumba”, zastosowaną wcześniej tylko przez Fiedlera ${ }^{103}$. Podkreśliła wielką popularność książek pisarza o Madagaskarze, pisząc:

[...] do dziś Polacy kojarzą tego podróżnika i przyrodnika przede wszystkim z tajemniczą Czerwoną Wyspą, a Madagaskar - z lemurami $^{104}$.

O słuszności opinii badaczki świadczą głosy i wypowiedzi czytelników, dostępne na internetowych portalach czytelniczych. Internauci orientują się w różnicach między książką Jutro na Madagaskar!, a późniejszymi przeróbkami. Nieliczne osoby znają, zaś wiele pragnie przeczytać najstarszy reportaż autora o Madagaskarze ${ }^{105}$ oraz Żarliwa wyspę

98 Zob. O. Budrewicz, Madagaskar - pełen tajemnic, Warszawa 1986, s. 21.

99 T. Owsiany, Tomek na czerwonej wyspie, zdjęcia T. Owsiany, opracowanie plastyczne W. Cejrowski, Pelplin 2013, s. 123.

100 D. Kozioł, Mój Madagaskar, Sandomierz 2011, s. 5.

101 J.W. Dyskant, Madagaskar 1942, Warszawa 2010, s. 17-18.

102 Zob. Cz. Drążek, Błogosławiony Ojciec Jan Beyzm SJ. Posługacz trędowatych. Biografia, Kraków 2002, s. 7, 202.

103 K. Marcinkowska, Od - tworzyć przeszłość. Kult czumba na Madagaskarze, Gdańsk 2016, s. 10, 73-74.

104 Tamże, s. 74.

105 Portal internetowy lubimyczytac.pl [online] [dostęp 17 kwietnia 2018]. Dostępny w World Wide Web: http://lubimyczytac.pl/ksiazka/73611/jutro-na-madagaskar. 
Beniowskiego ${ }^{106}$ i osobne wydanie Radosnego ptaka Drongo ${ }^{107}$. Do powszechnie znanych tytułów należą Gorq̨ca wieś Ambinanitelo, Wyspa kochających lemurów i Madagaskar okrutny czarodziej. Odbiorcy literatury deklarują na temat tych książek prawie jednogłośnie: „przeczytane”, nieraz wykazując się dobrą znajomością fabuł, są też czytelnicy informujący o bieżącej lekturze, chcący je poznać albo, zafascynowani, sięgnąć po inne publikacje A. Fiedlera. Część miłośników reportaży podróżniczych poznała je nie w postaci drukowanej, ale w formie audiobooka lub e-booka ${ }^{108}$. Najbardziej popularna pozycja to Gorq̨ca wieś Ambinanitelo ${ }^{109}$, głównie dzięki edycji z 2006 r.

\section{Podsumowanie}

Książki A. Fiedlera na temat Madagaskaru należą do kanonu polskiej literatury podróżniczej. Nie jest to kanon martwy, lecz wzbudzający zainteresowanie i emocje, o czym świadczą opinie czytelników. Dowodzi tego także przywoływanie publikacji autora przez twórców współczesnych reportaży oraz prac popularyzatorskich.

O dobrej recepcji spuścizny podróżnika decyduje lekki styl pisarza, powodujący łatwe wciąganie się dużej części odbiorców w odprężającą

106 Portal internetowy lubimyczytac.pl [online] [dostęp 17 kwietnia 2018]. Dostępny w World Wide Web: http://lubimyczytac.pl/ksiazka/73645/zarliwa-wyspa-beniowskiego.

107 Portal internetowy lubimyczytac.pl [online] [dostęp 17 kwietnia 2018]. Dostępny w World Wide Web: http://lubimyczytac.pl/ksiazka/73636/radosny-ptak-drongo.

108 Portal internetowy lubimyczytac.pl [online] [dostęp 17 kwietnia 2018]. Dostępny w World Wide Web: http://lubimyczytac.pl/ksiazka/228626/wyspa-kochajacych-lemurow, http://lubimyczytac.pl/ksiazka/56263/madagaskar-goraca-wies-ambinanitelo, http://lubimyczytac.pl/ksiazka/55900/madagaskar-okrutny-czarodziej; portal internetowy biblionetka.pl [online] [dostęp 17 kwietnia 2018]. Dostępny w World Wide Web: http:// biblionetka.pl/book.aspx?id=4166.

109 Portal internetowy lubimyczytac.pl [online] [dostęp 17 kwietnia 2018]. Dostępny w World Wide Web: http://lubimyczytac.pl/ksiazka/56263/madagaskar-goraca-wies-ambinanitelo; portal internetowy nakanapie.pl [online] [dostęp 17 kwietnia 2018]. Dostępny w World Wide Web: http://nakanapie.pl/madagaskar-goraca-wiesambinanitelo-arkady-fiedler-ksiazka,394323; portal internetowy granice.pl. wszystko o literaturze [online] [dostęp 17 kwietnia 2018]. Dostępny w World Wide Web: http:// granice.pl/ksiazka/madagaskar-goraca-wies-ambinanitelo/263143; portal internetowy biblionetka.pl [online] [dostęp 17 kwietnia 2018]. Dostępny w World Wide Web: http:// biblionetka.pl/book.aspx?id=4166. 
lekturę, dającą rozrywkę i wiedzę o świecie, wzbogaconą starannie opracowanym materiałem fotograficznym. Wciągająca narracja może dawać niektórym osobom wrażenie podróży w przestrzeni i czasie. Duże znaczenie ma też wielotematyczność reportaży A. Fiedlera. Można w nich znaleźć informacje z różnych dziedzin wiedzy: geografii, historii, przyrody, etnografii, o sprawach politycznych, gospodarczych i społecznych. Sympatię, okazywaną publikacjom autora przez czytelników, powodują też walory wychowawcze lektury. Reporter przekonuje do tolerancji wobec obcych kultur, zniechęca do rasizmu, kształtuje wrażliwość na problemy socjalne i choroby, przekazuje miłość do przyrody oraz humanitarny stosunek wobec zwierząt. Uczy patriotyzmu, przypominając zasługi, jakie nasi rodacy mieli na obczyźnie.

Fakt wprowadzania do książek elementów propagandy politycznej nie odbiera wartości publikacjom, bo autor propagując przejściowe koncepcje i ideologie polityczne, zawsze jednocześnie popularyzował wartości ponadczasowe. Obecnie Jutro na Madagaskar! (1939) i pierwsze wydanie Gorącej wsi Ambinanitelo (1953) można traktować jako dokumenty czasów, w jakich powstały. Przeciętny czytelnik naturalnie chętniej sięgnie po Wyspę kochających lemurów oraz edycję Gorącej wsi Ambinanitelo w serii Biblioteka Poznaj Świat i książkę Madagaskar okrutny czarodziej.

Książki A. Fiedlera trzeba polecać czytelnikom z uwagi na walory poznawcze, wychowawcze i rozrywkowe. Lektura w wielu przypadkach zaowocuje rozbudzeniem u odbiorców zainteresowania opisywaną tematyką, a także dążeniem do poznania bardziej współczesnych publikacji książkowych i filmów dokumentalnych.

\section{Bibliografia:}

\section{Publikacje drukowane:}

Arkady Fiedler. Poradnik bibliograficzny, oprac. Urszula Bzdawka, Poznań 1984. Baker John Norman Leonard, Odkrycia i wyprawy geograficzne, tt. Jan Flis, Warszawa 1959.

Beniowski Maurycy, Pamiętniki, tł. Edward Kajdański, Warszawa 1995. 
BT [Barbara Tylicka], Fiedler Arkady, ur. 1894 w Poznaniu, zm. 1985, [w:] Słownik literatury dziecięcej i młodzieżowej, red. Barbara Tylicka, Grzegorz Leszczyński, Wrocław, Warszawa, Kraków 2002, s. 116-117.

Budrewicz Olgierd, Madagaskar - pełen tajemnic, Warszawa 1986.

[Cejrowski Wojciech], Kilka słów o zdjęciach, [w:] Arkady Fiedler, Madagaskar goraca wieś Ambinanitelo, opracowanie plastyczne Wojciech Cejrowski, Pelplin 2006, s. 349-350.

Centkiewicz Czesław Jacek, Lemury i dziewczyny, „Wiadomości Literackie” 1939, nr 4, s. 5.

Drążek Czesław, Błogosławiony Ojciec Jan Beyzm SJ. Posługacz trędowatych. Biografia, Kraków 2002.

Dyskant Józef Wiesław, Madagaskar 1942, Warszawa 2010.

E.G. [Ewa Głębicka], Fiedler Arkady (1894-1985), [w:] Wspótcześni polscy pisarze i badacze literatury. Słownik biobibliograficzny, red. Jadwiga Czachowska, Alicja Szałagan, t. 2: C-F, Warszawa 1994, s. 297-300.

Fiedler Arkady, Biada zwycięzcy! Z cyklu Gorqca wieś Ambinanitelo, „Wiadomości Polskie Polityczne i Literackie" 1940, nr 10, s. 3 [cz. 1].

Fiedler Arkady, Goraca wieś Ambinanitelo. Mimozy. Malgaski kogut, „Wiadomości Polskie Polityczne i Literackie" 1940, nr 28/29, s. 1 [cz. 2].

Fiedler Arkady, Gorąca wieś Ambinanitelo. Owady się modlą. Kameleon, „Wiadomości Polskie Polityczne i Literackie" 1940, nr 31, s. 3 [cz. 3].

Fiedler Arkady, Gorq̨ca wieś Ambinanitelo. Wzgórze Beniowskiego. Barwna śmierć, „Wiadomości Polskie Polityczne i Literackie” 1940, nr 34, s. 2 [cz. 4].

Fiedler Arkady, Gorq̨a wieś Ambinanitelo. Las jest moim przyjacielem. Pająki i modliszki, „Wiadomości Polskie Polityczne i Literackie” 1940, nr 38, s. 3 [cz. 5].

Fiedler Arkady, Gorq̨ca wieś Ambinanitelo. Duch Beniowskiego. Magia przyrody, „Wiadomości Polskie Polityczne i Literackie” 1941, nr 3, s. 2 [cz. 6].

Fiedler Arkady, Gorąca wieś Ambinanitelo. Głodna krew, „Wiadomości Polskie Polityczne i Literackie" 1941, nr 5, s. 2 [cz. 7].

Fiedler Arkady, Gorąca wieś Ambinanitelo. Wą̇ Ankoma, „Wiadomości Polskie Polityczne i Literackie" 1941, nr 8, s. 3 [cz. 8].

Fiedler Arkady, Gorq̨ca wieś Ambinanitelo, Warszawa 1953.

Fiedler Arkady, Madagaskar - gorąca wieś Ambinanitelo, oprac. plastyczne Wojciech Cejrowski, Pelplin 2006.

Fiedler Arkady, Jutro na Madagaskar!, Warszawa 1939.

Fiedler Arkady, Jutro na Madagaskar!, Wyd. 3, Warszawa 1940.

Fiedler Arkady, Kobiety mej młodości. Rzeczy wybrane, Poznań 1989. 
Fiedler Arkady, Madagaskar okrutny czarodziej, Wyd. 3, Warszawa 1982.

Fiedler Arkady, Motyle mego życia. O wielkiej miłości i wielu miłostkach, Poznań 1983.

Fiedler Arkady, Radosny ptak Drongo, Lechtworth Herts, Lechtworth Print 1946. Fiedler Arkady, Radosny ptak Drongo, „Przekrój” 1946, nr 78, s. 19-20.

Fiedler Arkady, Wiek męski - zwycięski, Poznań 1983.

Fiedler Arkady, Wyspa kochających lemurów, Wyd. 3, Warszawa 1986.

Fiedler Arkady, Zwierzęta mego życia. Rzeczy wybrane, Poznań 1985.

Fiedler Arkady, Żarliwa wyspa Beniowskiego, Lechtworth Printers Ltd, Lechtwoth Herts 1944.

Fiedler Arkady Radosław, Barwny świat Arkadego Fiedlera, Poznań 1977.

Fiołka Katarzyna, Fiedler, Warszawa 2011.

Giełżyński Wojciech, Fiedler znów z Madagaskaru, „Nowe Książki” 1969, nr 9, s. 597-598.

H.J. [Henryk Jezierski], Madagaskar dzisiaj, „Nasz Klub”1974, nr 10, s. 24.

Hulewicz Witold, Madagaskar Fiedlera, „Pion” 1939, nr 5, s. 5.

Jarnecki Michał, Madagaskar w polskich koncepcjach i planach kolonialnych, „Sprawy Narodowościowe. Seria Nowa” 2006, z. 28, s. 89-101.

Jas [Paweł Jasienica], Odpowiadam czytelnikom, „Tygodnik Powszechny” 1946, nr 44, s. 12.

Jernas Oskar, Arkady Fiedler. Człowiek bez paszportu, Poznań 2013.

Jezierski Henryk, Madagaskar Fiedlera, „Książki dla Ciebie” 1972, nr 10 (dodatek do miesięcznika „Nasz Klub”), s. 22.

Kaden-Bandrowski Juliusz, „Jutro na Madagaskar”, „Gazeta Polska” 1939, nr 8, s. 12.

Kajdański Edward, Przedmowa tłumacza, [w:] Maurycy Beniowski, Pamiętniki, tł. Edward Kajdański, Warszawa 1995, s. [7]-18.

Kempiński Tomasz, Egzotyczny świat Arkadego Fiedlera, „Argumenta Historica. Czasopismo Naukowo-Dydaktyczne” 2016, nr 3, s. 42-59.

Kozioł Dorota, Mój Madagaskar, Sandomierz 2011.

Kuffel Józef, Arkady Fiedler. Podróżnik i literat, Bydgoszcz, Puszczykowo 2012. Lachnitt Walerian, Egzotyka, „Kultura” 1939, nr 18, s. 6.

Lepecki Mieczysław Bohdan, Madagaskar. Kraj. Ludzie. Kolonizacja, Warszawa 1938.

Marcinkowska Karolina, Od - tworzyć przeszłość. Kult czumba na Madagaskarze, Gdańsk 2016.

mn, Zacofane obyczaje Malgaszów, „Kuźnica” 1946, nr 42, s. 11. 
Owsiany Tomasz, Tomek na czerwonej wyspie, zdj. Tomasz Owsiany, oprac. plastyczne Wojciech Cejrowski, Pelplin 2013.

Polo Marco, Opisanie świata, tł. Anna Ludwika Czerny, wstępem i przypisami opatrzył Marian Lewicki, tł. przedmowy Umberto Eco Joanna Wajs, Warszawa 2010.

Pruszyński Ksawery, Arkady Fiedler: „Jutro na Madagaskar”, Tow.[arzystwo] Wyd. [awnicze] Rój, Warszawa 1939, str. 280, „Kurier Literacko-Naukowy” 1939, nr 2, s. X-XI (dodatek do nr 9 „Ilustrowanego Kuriera Codziennego”).

Ratajczak Józef, Gdy Warta wpadała do Ukajali (szkice o Arkadym Fiedlerze), Poznań 1994.

Ratajski Lech, Afryka, Warszawa 1966.

Roszko Janusz, Fiedler - egzotyczny czarodziej?, „Życie Literackie” 1985, nr 16, s. 1,13 .

Sadkowski Wacław, Nowa powieść Konwickiego - Wybór słuchowisk literackich Wspomnienia Michała Rusinka - Reportaże publicystyczne i literackie - „Antypowieść” Aragona, „Nowa Szkoła” 1970, nr 1, s. 50-51.

Tylicka Barbara, Arkady Fiedler, Warszawa 1989.

Walkowska Wiesława, Podróże z Arkadym Fiedlerem, Warszawa 2014.

Wasita Ryszard, Przyjaciel Malgaszów i kanadyjskich sosen, „Nowa Kultura” 1954, nr 44, s. 6.

Wojt., Stołeczne szmery, „Przekrój” 1947, nr 115, s. [16].

\section{Publikacje elektroniczne:}

biblionetka.pl [online] [dostęp 17 kwietnia 2018]. Dostępny w World Wide Web: http://biblionetka.pl/book.aspx?id=4166.

granice.pl. wszystko o literaturze [online] [dostęp 17 kwietnia 2018]. Dostępny w World Wide Web: http://granice.pl/ksiazka/madagaskar-goraca-wies-ambinanitelo/263143.

lubimyczytac.pl [online] [dostęp 17 kwietnia 2018]. Dostępny w World Wide Web: http://lubimyczytac.pl.

Muzeum Arkadego Fiedlera w Puszczykowie [online] [dostęp 13 kwietnia 2018]. Dostępny w World Wide Web: http://fiedler.pl/.

nakanapie.pl [online] [dostęp 17 kwietnia 2018]. Dostępny w World Wide Web: http://nakanapie.pl/madagaskar-goraca-wies-ambinanitelo-arkadyfiedler-ksiazka,394323. 


\section{Classical travel reportage as a form of political propaganda and the transmission of knowledge about the world and culture. Arkady Fiedler's books on Madagascar}

ABSTRACT: The subject of the article are the books by Arkady Fiedler (1894-1985) about Madagascar, the effect of two writer's journeys to this African country, from 1937-1938 and 1965-1966: Jutro na Madagaskar! (1939), Żarliwa wyspa Beniowskiego of Beniowski (1944), Radosny ptak Drongo (1946), Goraca wieś Ambinanitelo (1953 and new editorial office from 2006), Wyspa kochajacych lemurów (1957), Madagaskar okrutny czarodziej (1969). The author of the study discusses the educational and propaganda message, constructed by the traveler in these publications in various historical and political realities, as well as the issue of reception of Fiedler's books on Madagascar. It is based mainly on the writer's reports and their reviews. It also includes Fiedler's memories, as well as the voices of people posting online on the literature portals. He shows that Fiedler's books are still arousing interest and emotions.

KEYWORDS: Fiedler Arkady (1894-1985), travel reportage, Madagascar. 